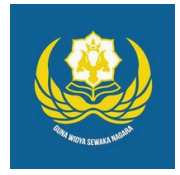

Jurnal Analogi Hukum

Journal Homepage: https://ejournal.warmadewa.ac.id/index.php/analogihukum

\title{
Penegakan Hukum Terhadap Selebgram yang Mempromosikan Situs Judi Online
}

\author{
Ignasius Yosanda Nono*, Anak Agung Sagung Laksmi Dewi dan I Putu Gede Seputra \\ Fakultas Hukum, Universitas Warmadewa, Denpasar, Bali-Indonesia \\ *ignasiusyosanda8@gmail.com
}

How To Cite:

Nono, I. Y., Dewi, A. A. S. L., \& Seputra, I. P. G. (2021). Pertanggungjawaban Penegakan Hukum Terhadap Selebgram yang Mempromosikan Situs Judi Online. Jurnal Analogi Hukum. 3 (2). 235-239. Doi: https://doi.org/10.22225/ah.3.2.2021.235-239

\begin{abstract}
Celebgrams or the acronyms for celebrities and Instagram are those that are well known through the social media Instagram. Celebrities are not much different from celebrities in general. The difference between celebrities and celebrities in general lies only in the medium. If most celebrities are famous for their appearance on the screen, a celebrity is famous for their presence on Instagram social media. The viral figure of celebrities on Instagram is used as an opportunity for business people to endorse / promote gambling sites through the Instagram account belonging to this celeb. The formulation of the problem that can be raised is How is law enforcement regarding the promotion of online gambling sites? What are the criminal sanctions against celebrities who promote online gambling sites? This thesis uses a type of normative legal research, Law Number 11 of 2008 concerning Electronic Information and Transactions, the Criminal Code is the legal basis for knowing legal arrangements and legal sanctions against celebrities promoting online gambling sites. The results of this study indicate that the imposition of legal sanctions on celebrities.
\end{abstract}

Keywords: Law enforcement; Celebgram; Online gambling site.

\begin{abstract}
Abstrak-Istilah selebgram atau selebritis media instagram adalah seseorang yang terkenal pada aplikasi media sosial instagram melalui karya-karya yang dihasilkan pada bidang fashion, teknologi, ilmu pengetahuan, kuliner dan lainnya, kemunculan istilah selebgram ini sebenarnya tidak jauh berbeda dengan selebritis yang muncul di layar kaca televisi. Viralnya sosok selebgram pada Instagram di jadikan peluang bagi pelaku usaha untuk mengendorse, mempromosikan situs judi melalui akun Instagram milik selebgram tersebut. Rumusan masalah yang dapat diangkat yaitu Bagaimana penegakan hukum tentang promosi situs judi online?,Bagaimana sanksi pidana terhadap selebgram yang mempromosikan situs judi online? Skripsi ini menggunakan tipe penelitian hukum normatif, Undang Undang Nomor 11 Tahun 2008 Tentang Informasi dan Transaksi Elektronik, Kitab Undang-undang Hukum Pidana menjadi dasar hukum untuk mengetahui pengaturan hukum dan sanksi hukum terhadap selebgram yang mempromosikan situs judi online. Hasil penelitian ini menunjukan bahwa penjatuhan sanksi hukum terhadap selebgram dilakukan berdasarkan Undang -Undang Nomor 11 Tahun 2008 tentang Informasi dan Transaksi elektronik karena telah melakukan promosi situs judi online.
\end{abstract}

Kata Kunci: Penegakan Hukum; Selebgram; Situs judi online.

\section{Pendahuluan}

Di era globalisasi ini, penggunaan internet semakin berkembang dari hari ke hari. Dengan berkembangnya teknologi internet, banyak bermunculan media sosial, dan pengaruhnya yaitu banyaknya media sosial seolah membuat orang ketagihan bermain media sosial. Media sosial juga sudah mulai menggantikan peran media elektronik dan media massa konvensional, karena masyarakat beranggapan bahwa media sosial sangat cepat dalam menyebarkan berita atau informasi. Media sosial menyediakan dunia baru bagi masyarakat, dan media sosial digunakan sebagai dunia bisnis masyarakat. Dalam hal ini dunia bisnis adalah bisnis online.

Pesatnya perkembangan teknologi informasi yang melanda berbagai negara di seluruh dunia saat ini memang tidak dapat dipungkiri lagi, seiring berkembangnya 
teknologi informasi membuat berbagai kemudahan terhadap aktivitas konvensional yang dilakukan oleh masyarakat, diantaranya dengan kemunculan situs judi online yang sudah tidak dilakukan secara konvensional lagi. (Mansur \& Gultom, 2005).

Munculnya sosial media Instagram menyebabkan munculkan selebgram, yang dalam hal ini selebgram adalah seorang selebriti atau publik figure dalam media sosial instagram, dengan banyaknya pengikut dalam akun sosial media Instagram milik selebgram tersebut dijadikan peluang bisnis oleh pelaku usaha untuk mempromosikan situs judi online pada akun selebgram tersebut, yang bertujuan agar para pengikut dalam akun Instagram selebgram tersebut mau mengikuti situs judi online yang telah dipromosikan oleh selebgram tersebut.

Pada sebelum nya pelaku usaha dapat memasang iklan baik melalui media elektronik, (televisi, radio, internet), maupun media elektronik (majalah, surat kabar, billboard) (Harianto, 2010), Tapi di era sekarang ini, efek menggunakan benda-benda ini untuk promosi tidak baik, dan orang tidak peduli. Seiring dengan berkembangannya teknologi serta informasi serta laju pertumbuhan internet membuat internet menjadi salah satu media yang efektif bagi pelaku usaha untuk mempromosikan situs judi online kepada masyarakat dari seluruh dunia yang kita kenal sebagai transaksi tanpa kertas (paperless) dan tidak bertemu secara langsung (face to face) (Barkatullah, 2009)

Melalui internet (internet gambling) jasa selebgram dan paid promote untuk promosi, istilah populer yang dikenal saat ini yang berkaitan dengan promosi yang dilakukan melalui media sosial instagram adalah endorse dan/atau endorsement. Pelaku usaha dapat memanfaatkan jasa selebgram yang memiliki banyak pengikut di akun sosial media instagramnya guna mengembangkan usaha yang dimilikinya agar diketahui oleh khalayak pada umumnya, termasuk juga situs judi online yang marak beredar belakangan ini, kemunculan judi online saat ini sangat signifikan dari beberapa tahun sebelumnya, hal tersebut tidak lepas dari jasa promosi yang dilakukan oleh selebgram pada akun media sosialnya. Banyak para selebgram atau infuser membuka jasa endorse, paid promote dimana hal ini dimanfaatkan oleh bandar judi online untuk menawarkan kepada selebgram atau influencer untuk mempromosikan situs mereka dengan bayaran yang fantastis setiap bulannya.
Tipe promosi yang kedua yang pada umumnya dilakukan bandar judi adalah melalui bonus. Jadi bandar judi menyimpan banyak bonus kepada calon member agar mau bergabung dengan mereka dan memberikan itu juga untuk membuat member setia mereka betah melakukan taruhan. Jenis bonusnya sendiri juga bervariasi. Satu, ada bonus new member atau member baru yang akan langsung didapatkan ketika member gabung dengan web perjudian online. Lalu juga ada promosi selanjutnya yaitu bonus deposit, yang akan didapatkan setiap member setelah melakukan setor tunai. Besarnya bonus deposit tergantung dengan uang tunai yang mereka setorkan ke agen judi Sbobet (Rahardjo, 2003)

Selanjutnya juga ada promosi paling menarik bagi member yaitu berupa bonus referral. Kenapa saya bilang menarik karena promo satu ini sangat menguntungkan dan cara mendapatkannya cukup mudah. Kita hanya perlu membawa orang baru untuk jadi member dari situs bandar judi yang kita ikuti. Setiap member yang berhasil kita bawa, kita biasanya akan langsung diberikan saldo cuma-cuma dari 10 ribu sampai 25 ribu, tergantung ketentuan agen judi yang kita ikuti. Promosi ini juga sangat menguntungkan karena juga tidak memiliki limit atau batas. Semakin banyak orang baru yang berhasil kita bawa gabung, semakin besar hadiah referral kita.

Selebihnya, promosi ini juga bisa berupa bonus cashback dan bonus rollingan, yang pasti tidak kalah menguntungkan dari yang saya sebutkan tadi. Dan sudah saya bilang atau sampaikan di atas, bahwa terdapat agen resmi dan agen palsu dalam persaingan bisnis judi online. Dan pastinya untuk bisa mendapatkan promo di atas khususnya yang berupa bonus, kita perlu menjadi member dari agen judi terpercaya, contohnya pada kasus promosi judi online yang dilakukan oleh selebgram yang berhasil diungkap oleh Kepolisian Daerah Bengkulu, pada Praktek promosi judi online ini dilakukan oleh seorang wanita berinisial MK ditangkap tim Subdit V Siber Ditreskrimsus Polda Bengkulu telah diketahui mempromosikan Situs Judi Online.

Mengenai kegiatan perjudian tela diatur di dalam pasal 303 Wetboek Van Staatrech atau yang biasa di sebut dengan Kitab UndangUndang Hukum Pidana apabila kegiatan perjudian tersebut dilakukan secara konvensional, apabila kegiatan perjudian tersebut dilakukan melalui media maya atau media elektronik, maka hal tersebut telah diatur di dalam Pasal 27 ayat 2 Undang-Undang Nor 11 tahun 2008 tentang Informasi dan Transaksi 
Elektronik.

Berdasarkan uraian permasalahan diatas, dapat ditarik rumusan-rumusan masalah diantaranya yaitu: Bagaimana penegakan hukum tentang promosi situs judi online?dan Bagaimana sanksi pidana terhadap selebgram yang mempromosikan situs judi online?

Sehingga tujuan dilakukannya penelitian ini adalah Untuk memahami Bagaimana penegakan hukum tentang promosi situs judi online dan Untuk memahami Bagaimana sanksi pidana terhadap selebgram yang mempromosikan situs judi online.

\section{Metode}

Penelitian yang penulis gunakan adalah penelitian hukum normatif (Hartono, 1994) yaitu penelitian dilakukan dengan menganalisis peraturan perundang-undangan yang berlaku. Mengenai sumber bahan hukum yang digunakan terbagi atas Bahan Hukum Primer adalah bahan hukum yang utama yang menjadi dasar kajian dari penulisan artikel ini.

Bahan Hukum sekunder adalah adalah bahan hukum yang digunakan untuk menunjang atau membantu dalam memberikan pemahaman -pemahaman dan gambaran-gambaran serta teori-teori hukum yang digunakan untuk mengulas dan memecahkan persoalan-persoalan yang akan di teliti di dalam penelitian penulisan skripsi. Selanjutnya Bahan Hukum Tersier adalah bahan hukum yang memberikan pedoman dan interpretasi bagi bahan hukum tingkat pertama dan kedua.

Teknik pengumpulan bahan dalam penelitian menggunakan teknik studi pustaka (library research) yaitu membaca, mencatat, mengutip, meringkas, dan menelaah informasi data dari peraturan atau literatur yang terkait dengan masalah tersebut. Setelah bahan hukum telah terkumpul melalui proses studi pustaka, dalam menganalisis bahan hukum yang telah terkumpul dalam penelitian ini penulis menggunakan uraian teknis, sistematisasi, argumentasi dan interpretasi hukum berdasarkan logika deduktif dan induktif.

Ditinjau sesuai kebutuhan dengan menggunakan pendekatan kualitatif. Selanjutnya setelah bahan hukum primer dan sekunder terkumpul, ini akan diolah dan dianalisis menggunakan metode penanganan bahan hukum yang sistematis (Sunggono, 2002)

\section{Hasil dan Pembahasan}

Penegakan Hukum Terhadap Selebgram Yang Melakukan Endorse/Promosi Situs Judi Online

Promosi merupakan kegiatan penyebarluasan informasi suatu barang/produk yang tujuannya adalah untuk menarik minat dari masyarakat sebagai konsumen. Dengan adanya kegiatan promosi dapat menunjang pendapatan dari penjualan yang didapatkan oleh pelaku usaha. Semakin berkembangnya kegiatan promosi, kini promosi dilakukan oleh selebriti pada social media Instagram atau sering disebut sebagai selebgram.

Pengaruh promosi yang dilakukan oleh selebgram sangat efektif sehingga pelaku usaha mendapatkan keuntungan yang banyak dari postingan yang dilakukan oleh selebgram melalui akun instagramnya, karena mendapatkan banyak keuntungan sehingga hal tersebut yang dijadikan motivasi untuk melakukan kegiatan usaha. Biasanya promosi yang dilakukan melalui media cetak kurang menarik dan masyarakat kurang memperhatikan promosi tersebut. Dalam Undang- undang No 8 Tahun 1999 tentang Perlindungan Konsumen, pada Pasal 1 ayat (6) menyatakan bahwa kegiatan promosi adalah pemberian informasi kepada masyarakat tentang suatu produk yang diperdagangkan oleh pelaku usaha yang tujuannya untuk menarik minat dari masyarakat untuk membeli produk tersebut. Untuk menjalankan kegiatan promosi, pelaku usaha melakukan kerja sama dengan Selebgram dalam mempromosikan produk yang diperdagangkannya.

Dengan pelaku usaha yang mempromosikan situs judi online yang memberikan informasi yang benar, jelas dan jujur mengenai kondisi produk otomatis masyarakat yang menjadi konsumen merasa percaya atas promosi tersebut. Penyampaian informasi yang benar terhadap para konsumen dari pelaku usaha sangat penting, agar mengetahui mengenai gambaran suatu produk yang ditawarkan, agar tidak membahayakan kesehatan konsumen dikemudian hari (Rahardjo, 2003)

pelaku usaha diharuskan untuk tidak melakukan tindakan-tindakan yang menyalahi aturan dalam melakukan promosi sesuai dengan Pasal 9 ayat (1) yang mengatur mengenai tata cara melakukan promosi yang dilakukan secara konvensional maupun digital/online, dengan adanya Pasal 9 ayat (1) Undang- Undang No 8 Tahun 1999 Tentang Perlindungan Konsumen pelaku usaha menjadi tahu dalam bertindak untuk melakukan promosi produk yang 
diperdagangkan. Segala sesuatu yang berkaitan dengan hal-hal yang menyimpang pada pasal tersebut harus dijauhi oleh pelaku usaha, agar kegiatan promosi menjadi lebih baik dan tidak adanya kebohongan antara pelaku usaha dan konsumen.

Di samping itu pelaku usaha harus memiliki keterbukaan terhadap selebgram yang dalam hal ini yang mempromosikan situs judi online kepada konsumen, sehingga segala sesuatu penyampaian informasi yang disampaikan oleh selebgram melalui akun media sosialnya dapat dipercaya oleh konsumen. Produk-produk yang tidak sesuai dengan yang dimaksud dalam Pasal 9 ayat (1) Undang-Undang No 8 Tahun 1999 Tentang Perlindungan Konsumen dilarang untuk diperdagangkan atau beredar di pasaran. Apabila pelaku usaha tidak menjalankan laranglarangan tersebut dalam melakukan promosi tentu pelaku usaha tersebut akan mendapatkan sanksi.

Menurut pendapat penulis bahwa dalam melakukan promosikan situs judi online melalui selebgram haruslah mematuhi undang-undang yang berlaku di Indonesia, Undang-Undang dalam hal ini menjadi batas atau kendali dalam melakukan kegiatan-kegiatan promosi agar terciptanya perdagangan yang sehat dan aman serta terjaminnya hak konsumen agar tidak ada yang dirugikan. Segala bentuk larangan yang telah diatur dalam Undang-Undang dalam melakukan kegiatan promosi pelaku usaha serta selebgram harus menjauhinya, tentu apabila melanggar ketentuan hukum yang ada akan dijatuhi hukuman sesuai pelanggaran yang telah dilakukan. Oleh sebab itu dalam melakukan kegiatan promosi harus jujur untuk mendapatkan kepercayaan dari pada konsumen. Apabila konsumen sudah percaya terhadap situs yang dipromosikan akan berdampak pada pendapatan penjualan yang semakin meningkat.

\section{Sanksi Hukum Terhadap Selebgram Yang Melakukan Endorse/Promosi Situs Judi Online}

Perkembangan teknologi informasi yang melanda negara-negara di seluruh dunia saat ini sangatlah pesat, hal tersebut dapat dilihat dari kemunculan cara komunikasi yang dapat dilakukan secara cepat oleh seseorang yang berada di penjuru dunia yang dapat dilakukan secara cepat dan tidak terbatas oleh ruang dan waktu untuk melakukan komunikasi (Sutarman, 2007). Dengan terjadinya perkembangan teknologi informasi yang terjadi saat ini dapat memunculkan berbagai masalah yang dilakukan melalui dunia maya atau yang biasa disebut dengan cyber crime, saat ini kejahatan yang dilakukan melalui dunia maya sudah menjadi momok atau musuh berbagai negara di seluruh dunia saat ini, mulai dari kejahatan dunia maya yang dilakukan secara translokal maupun internasional Oleh karena itu Undang-Undang Informasi, Transaksi, Elektronik ITE sangat dibutuh untuk membatasi hal-hal yang menyalahi aturan dalam perkembangan teknologi komunikasi dan informasi guna menciptakan ketentraman dalam kehidupan dalam bermasyarakat baik yang aktivitas yang dilakukan secara konvensional maupun melalui dunia maya.

Sanksi pidana merupakan suatu cara untuk dapat digunakan untuk mencapai tujuan diadakannya hukuman pidana, pemberian sanksi pidana hanya dapat dilakukan apabila seseorang telah bersalah karena melanggar suatu ketentuan peraturan perundang-undangan, sanksi pidana dengan pertanggungjawaban pidana memiliki konteks yang sama dengan pertanggungjawaban pidana, dimana sanksi pidana berlaku mutlak kepada seseorang yang telah melanggar suatu ketentuan peraturan perundang-undangan, dan tiada alasan pemaaf atas perbuatan yang telah dilakukan oleh seseorang tersebut, berbeda dengan pertanggungjawaban pidana, dimana pertanggungjawaban pidana dapat dikenakan kepada setiap orang karena telah bersalah dengan melanggar suatu ketentuan yang terdapat dalam peraturan perundang-undangan dan/atau dapat dipersalahkan akibat melanggar suatu ketentuan peraturan perundang-undangan, pada konteks pertanggungjawaban pidana, seseorang baru dapat dikenakan pertanggungjawaban pidana apabila seseorang tersebut dinyatakan layak untuk dapat dikenakan pertanggungjawaban pidana berdasarkan usia dan mental dari seseorang tersebut, dengan kata lain pada konteks pertanggungjawaban pidana terdapat alasan pemaaf bagi seseorang yang akan dikenakan pertanggungjawaban pidana.

Selebgram pemilik akun yang mempromosikan situs judi online pada akun media sosialnya dapat dikenakan pertanggungjawaban pidana berdasarkan ketentuan yang terdapat dalam Pasal 27 Ayat (2) UU ITE yang mengatur mengenai larangan untuk mendistribusikan atau mentransmisikan atau mengakses muatan elektronik yang mengandung perjudian, selain itu di dalam pasal 303 ayat (1) KUHP juga mengatur mengenai perjudian, di dalam KUHP perjudian tidak hanya perbuatan yang diatur dalam 
Undang-undang melainkan perbuatan yang dicela oleh masyarakat akibat mempromosikan situs judi online, berdasarkan hal tersebut mengenai promosi situs judi online yang dilakukan oleh selebgram dikatakan dapat memenuhi unsur-unsur yang terdapat di dalam UU ITE (Rahardjo, 2003).

Pemilik akun yang menerima endorsement dapatkan keuntungan berupa biaya jasa endorse dari pelaku usaha yang hendak mempromosikan barang dan/atau jasa. Oleh karena itu, berdasarkan teori kehendak, foto bermuatan judi disertai dengan caption foto dan adanya keuntungan yang didapatkan dari kegiatan endorsement membuktikan bahwa perbuatan menerima endorse dan membagikan foto bermuatan judi di Instagram merupakan suatu kehendak dan telah diketahui akibat perbuatannya. Mengenai sanksi pidana yang dijatuhkan terhadap selebgram yang melakukan promosi situs judi online pada akun instagram miliknya berdasarkan peraturan perundangundangan yang mengatur mengenai perbuatan perjudian, walaupun selebgram tersebut hanya melakukan promosi sebagaimana diatur dalam Pasal 303 KUHP Jo. Pasal 27 Ayat (2) UU ITE dengan ancaman pidana penjara paling lama 10 (sepuluh) tahun dan denda paling banyak $\mathrm{Rp}$. 25.000.000,00 (dua puluh lima juta rupiah).

\section{Simpulan}

Dari Pembahasan Dapat ditarik kesimpulan berdasarkan rumusan masalah yang sudah dibahas yaitu:

Berdasarkan kajian teoritis dan uraian pembahasan diatas, maka dapat disimpulkan bahwa Pemilik akun Instagram yang mempromosikan judi dalam hal menerima endorse dapat dikenakan pertanggungjawaban pidana berdasarkan ketentuan Pasal 27 ayat (2) UU ITE jo Pasal 55 KUHP.

Sanksi pidana yang dapat dijatuhkan terhadap selebgram yang mempromosikan situs judi online yaitu pidana berdasarkan ketentuan pasal 27 ayat (2) UU ITE jo. Pasal 55 KUHP. Pertanggungjawaban pidana tidak dapat serta merta dimintakan kepada pelaku tindak pidana karena ada unsur- unsur pertanggungjawaban yang harus semuanya terpenuhi, salah satunya unsur kesalahan. Bila penerima endorse illegal sebelumnya tidak mengetahui bahwa situs yang di promosikan illegal maka tidak ada unsur kesalahan, sehingga tidak dapat dipidana.

\section{Daftar Pustaka}

Bakatullah, A. H. (2009). Perlindungan Hukum Bagi Konsumen Dalam Transaksi E.
Commerce Lintas Negara di Indonesia. Yogyakarta: FH UII Press.

Harianto, D. (2010). Perlindungan Hukum bagi Konsumen terhadap Iklan Yang Menyesatkan. Jakarta: Ghalia Indonesia.

Hartono, S. (1994). Penelitian Hukum di Indonesia pada Akhir Abad ke-20. Bandung: Alumni

Mansur, D. M. A., \& Gultom, E. (2005). Cyber Law: Aspek Hukum Teknologi Informasi. Bandung: PT. Refika Aditama.

Rahardjo, A. (2003). Cybercrime Pemahaman dan Upaya Pencegahan Kejahatan Berteknologi. Bandung: PT.Citra Aditya Bakti.

Sunggono, B. (2002). Metodologi Penelitian Hukum, Cet. Keempat. Jakarta: PT Raja Grafindo Persada

Sutarman. (2007). Cyber Crime Modus Operandi dan Penanggulangannya. Yogyakarta: LaksBang PressIndo. 